\section{DOPADY PANDEMIE COVID-19 DO ŘíZENÍ A STRUKTURY ZDRAVOTNÍ PÉČE POSKYTOVANÉ LŮŽKOVÝMI ZDRAVOTNICKÝMI ZAŘ́́ZENÍMI}

\section{Miroslav Přádka, Eduard Sohlich}

\section{Anotace}

Pandemie COVID-19 představuje pro poskytovatele lůžkové zdravotní péče zásadní impuls ke změně struktury poskytované péče za situace, kdy klíčové rídící parametry (DRG systém, úhrady, regulace) vycházejí z referenčního období předcházejícího pandemii.

Příspěvek se zabývá analýzou vynucených změn ve struktuře a řízení poskytování zdravotní péče $v$ již ukončeném kalendářním roce 2020 včetně hodnocení efektu kompenzačních mechanizmů. Současně rámcově predikuje očekávané dopady realizovaných změn v roce 2021, a to na základě principů publikovaných $v$ príspěvcích semináře MEDSOFT v letech 2015 a 2019.

\section{Klíčová slova \\ pandemie, COVID-19, zdravotní péče, poskytovatel, kompenzace}

\section{1 Úvod}

S príchodem pandemie COVID-19 do teritoria Evropy v prvním čtvrtletí 2020 došlo postupně i k přizpůsobení činnosti zdravotnických systémů jednotlivých zemí novým potřebám. Šíření infekce $v$ Evropě zatížilo tyto systémy různou intenzitou $v$ různě časovaných dílčích vinách, které např. v České republice kulminovaly v intervalu od 2. poloviny roku 2020 do konce navazující 1. poloviny roku 2021. Ve srovnání s vybranými evropskými zeměmi představuje intenzita zátěže šíření COVID-19 v ČR spíše horší z dílčích kazuistik evropských zemí. Tuto skutečnost dokládáme vybranými ukazateli - jednak přepočteným kumulovaným počtem nakažených (viz obr. 1) a jednak přepočteným kumulovaným počtem zemřelých (viz obr. 2) sestavených na základě veřejně dostupných dat [1]. Pro prezentaci situace v ČR v kontextu současně využíváme i disponibilní data vybrané skupiny dalších evropských zemí - Rakouska, Španělska a Itálie.

Řešení zdravotního problému určité intenzity vyvolává následný tlak na financování. Zjištěná expanze výdajů vládních rozpočtů u sledovaných zemí paradoxně zcela nekoreluje s intenzitou zátěže vyvolané šiřením pandemie COVID-19. Na základě dat Eurostatu [2] uvádíme vývoj vládního dluhu v roce 2020 (viz obr. 3) a v prvním čtvrtletí 2021 (viz obr. 4) zohledněný vůči hrubému domácímu produktu dané země. Prezentovaná data vypovídají nejen o absolutní míre zadlužení, ale i o dynamice tvorby dluhu.

Kumulativní počet nakažených

COVID-19/ 1 mil. obyvatel - stav k 10. 8. 2021

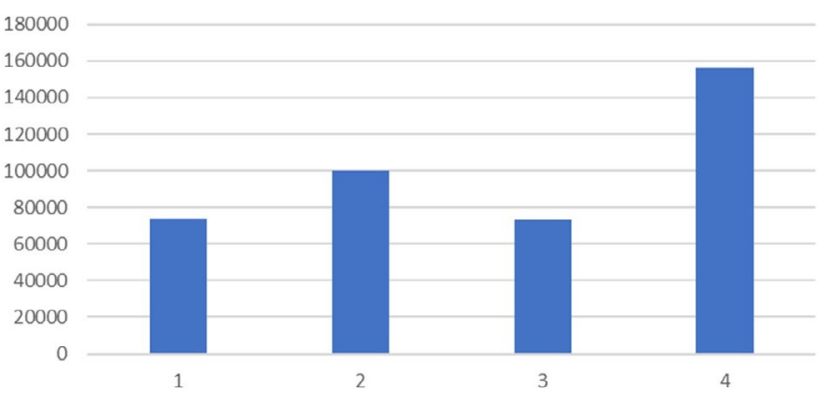

Obrázek 1 - Kumulativní počet nakažených COVID-19/1 mil. obyvatel dle [1]; legenda 1 - Rakousko, 2 - Španělsko, 3 - Itálie, 4 - Česká republika
Asociace českých a moravských nemocnic (AČMN) představuje sdružení více než sta poskytovatelů zdravotní péče lůžkového typu a prakticky všichni z nich se podíleli na zvládnutí problematiky COVID-19 v ČR. Ze zkušeností vyplývá, že komplexní zátěž související s léčbou COVID-19 pozitivních pacientů Ize členit do dílčích problematik, a sice do:

- vyvolaných strukturálních a logistických změn poskytované péče;

- úpravy úhradových mechanizmů a formy kompenzací;

- činnosti zdravotnického personálu ve změněných podmínkách.

\section{Dopady pandemie COVID-19 a následná opatření}

V prípadě výskytu pandemie postupuje lůžkové zdravotnické zařízení v souladu s principy zakotvenými v dokumentu zpracovaném pro tuto mimořádnou situaci, tedy $v$ souladu $s$ pandemickým plánem. Nakolik může obecně zpracovaný dokument do detailu specifikovat potřeby pro řešení situace výskytu nového onemocnění je diskutabilní, nicméně existence pandemických plánů byla při pandemickém šíření viru SARS-CoV-2 nepochybně výhodou.

\subsection{Strukturální a logistické změny poskytované péče}

Př́chod pandemie COVID-19 tedy znamenal aktivaci pandemických plánů (a mj. také přechod do stavu poskytování výhradně akutní péče lůžkovými zdravotnickými zařízeními) včetně vyčlenění a zprovoznění specializovaných lůžkových jednotek. V této souvislosti je nutno uvést, že celková lůžková kapacita jednotlivých zařízení je limitována a po celou dobu pandemie je zapotřebí poskytovat zdravotní péči také akutním „necovidovým" pacientům.

Ve vazbě na nutnost koordinace péče o "covidové" pacienty došlo také k centralizaci evidence př́slušných léčebných kapacit, a sice 1) k evidenci využité/disponibilní lůžkové kapacity (včetně možnosti oxygenoterapie), 2) k evidenci využité/disponibilní kapacity lůžek s ventilátorem a 3) k evidenci využité/ disponibilní kapacity ECMO.

Doplňujeme dále, že z hlediska vyžádané péče v zahraničí byla tato nezbytně poskytnuta jen ve zcela ojedinělých prípadech.

\section{2 Úpravy úhradových mechanizmů a formy kompen- zací}

V období předcházejícím pandemii byly úhrady zdravotní péče nastaveny zpravidla úhradovými vyhláškami, které poměrně detailně zohledňovaly výkonnost jak ambulantní, tak lůžkové části zdravotnického zařízení včetně tzv. elektivní péče. Samotný úhradový konstrukt vychází obvykle z cenotvorby založené

Kumulativní počet zemřelých

COVID-19/ 1 mil. obyvatel - stav k 10. 8. 2021

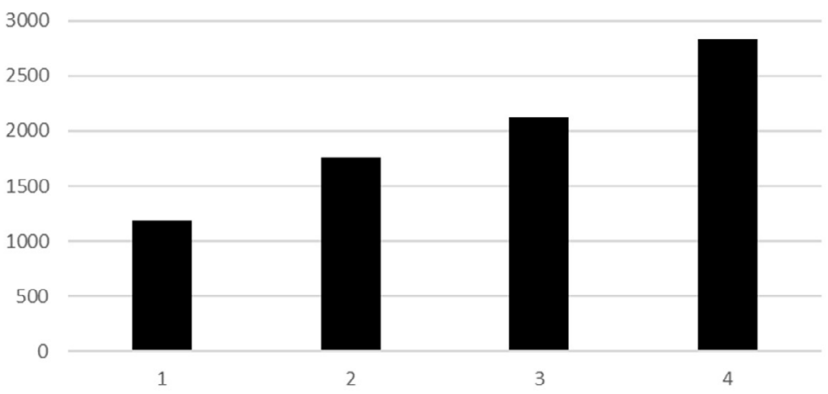

Obrázek 2 - Kumulativní počet zemřelých COVID-19/1 mil. obyvatel dle [1]; legenda 1 - Rakousko, 2 - Španělsko, 3 - Itálie, 4 - Česká republika 


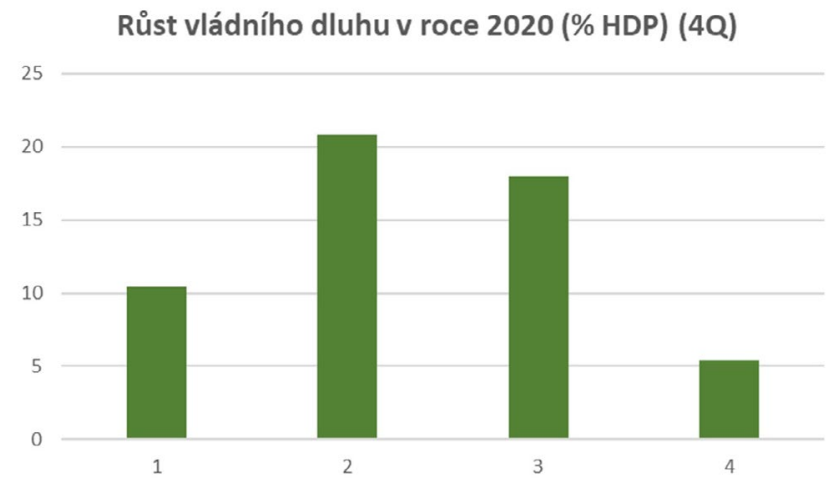

Obrázek 3 - Růst vládního dluhu v roce 2020 dle [2]; legenda 1 - Rakousko, 2 - Španělsko, 3 - Itálie, 4 - Česká republika. (General government gross debt [2])

na bodovém ohodnocení jednotlivých zdravotních výkonů včetně rozdílných korunových hodnot bodu u jednotlivých zdravotnických odborností a na využití modifikovaného DRG systému u úhrad lůžkové péče; dále úhradový konstrukt předpokládá vazbu na výkonnost zdravotnického zařízení v referenčním období. $Z$ důvodu jednoduchosti neuvažujeme úhradové dopady přesunu pojištěnců mezi pojištovnami a další dílčí regulatorní či penalizační opatření.

Aktivace pandemických plánů se změnou typového profilu pacienta (COVID-19+) má u jednotlivého zdravotnického zařízení, s ohledem na výše uvedené, dopady do výše úhrad:

- celkové ambulantní složky zdravotní péče,

- celkové lůžkové složky zdravotní péče,

- celkové elektivní péče.

Formy kompenzace úhrad péče dle [3] se zaměřují především na kompenzaci úhrad za péči pro COVID-19+ pacienty, kompenzace dle [4] dále akcentuje bonifikaci personálu podílejícího se na léčbě těchto pacientů.

Pro stabilizaci $v$ post-covidovém období považujeme za účelné minimalizovat vyvolané mimorádné úhradové vlivy, a to včetně diskuze o jednodušším a lépe obhajitelném úhradovém mechanizmu než je obvyklý úhradový konstrukt. (Má ještě vůbec smysl ohodnocovat zdravotnické výkony $v$ bodech a následně hodnoty těchto bodů stanovovat v Kč pro jednotlivé odbornosti?)

\section{3 Činnost zdravotnického personálu v období pan- demie COVID-19}

- Nemocnice byly nuceny zareagovat vytvořením týmů pečujících o pacienty na covidových jednotkách (akutní, intenzivní i následné péče). Výrazně na těchto jednotkách vzrostla zátěž zdravotnických pracovníků - časová a fyzická (ochranné pomůcky), psychická (těžké, často infaustní stavy, tlak rodinných přislušníků).

- Rozdělením do infekčních a neinfekčních týmů se týmy početně oslabily (nové pracovníky není kde brát!) a zvýšila se proto zátěž personálu i na neinfekčních odděleních (přesčasová práce).

- Nemocnice $v$ tomto období čelily př́sunu pacientů z terénních ambulancí, které z výrazné části ordinovaly po telefonu. Logickým důsledkem bylo konečné ošetření v nemocni$c i$, zejména v době pohotovostní služby.

- V plné nahotě se tak projevila politicky dlouhodobě podceňovaná personální kapacita pracovníků v nemocnicích, způsobována zejména:

- nedostatečným společenským a finančním oceněním

- bezbřehá eskalace kapacit terénních ambulancí bez povinnosti participace na ústavní péči
Růst vládního dluhu v 1.Q. 2021 (\%HDP) (1Q)

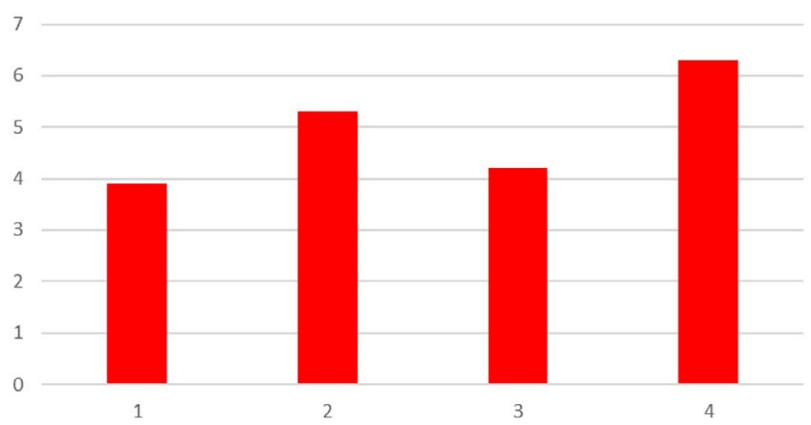

Obrázek 4-Růst vládního dluhu v 1. Q. 2021 dle [2]; legenda 1 -Rakousko, 2 - Španělsko, 3 - Itálie, 4 - Česká republika. (General government gross debt [2])

- početně i strukturálně zanedbané pre- i postgraduální vzdělávání lékařských i nelékařských pracovníků

\section{Závěr}

Dopady pandemie COVID-19 do českého zdravotnického systému jsou komplexní a prostý návrat do období předcházejícího pandemii nebude zřejmě možný.

Za určující pro další období považujeme:

- Efektivní zvládnutí změny struktury poskytované péče v post-covidovém období;

- Personální stabilizaci zdravotnictví;

- Zjednodušení a optimalizaci úhradových mechanizmů;

- Vyřešení otázky cenotvorby ve zdravotnictví

- Širší implementaci nástrojů e-Health [5, 6].

Za cíle realizovaných opatření pak považujeme zejména kvalitu a dostupnost zdravotní péče, a současně stabilitu i předvídatelnost jejího financování.

\section{Literatura}

[1.] https://www.worldometers.info/coronavirus/

[2.] https://ec.europa.eu/eurostat/databrowser/view/teina230/default/ table?lang=en;

[3.] Ministerstvo zdravotnictví ČR: Vyhláška č. 305/2020 Sb.

[4.] Ministerstvo zdravotnictví ČR: Vyhláška č. 170/2021 Sb.

[5.] Přádka, M.: Náklady a výnosy e-Health z pohledu poskytovatelů péče, In: Proc. of MEDSOFT 2015, ISSN 1803-8115, ISBN 978-80-90600-42-3, ISBN 978-80-86742-40-3, 2015, pp. 184-186;

[6.] Prádka, M.: E-Health a zvyšování konkurenceschopnosti poskytovatelů zdravotní péče, In: Proc. of MEDSOFT 2019, ISSN 1803-8115, ISBN 978-80-86742-46-5, ISBN 978-80-906752-0-9, 2019, pp. 65-67; DOI: 10.35191/MEDSOFT 2019 1 1316567.

\section{Kontakt}

Ing. MUDr. Miroslav Prádka, Ph. D.

MUDr. Eduard Sohlich, MBA

Asociace českých a moravských nemocnic (AČMN)

Bělocerkevská 18

10000 Praha 10

e-mail:acmn@acmn.cz 